\title{
Efektivitas Program Membangun Keluarga Utama sebagai Program Pemberdayaan Masyarakat Islami (Studi Kasus di KSPPS BMT Tumang)
}

\author{
M. Qoshid Al Hadi \\ Universitas Darussalam Gontor, Ponorogo, Jawa Timur, 63471, Indonesia \\ qoshid_alhadi@unida.gontor.ac.id
}

ARTICLE INFO

Article history:

Received : 2019-01-31

Revised : 2019-03-28

Accepted : 2019-05-23

Keywords:

Effectiveness,

Empowerment,

MKU Program

Kata Kunci:

Efektivitas,

Pemberdayaan,

MKU Program

\section{ABSTRACT}

Poverty alleviation is a development general agenda all over the world, including Indonesia. Quality and sustainable development is the development capabling of empowering people to alleviate poverty and improve quality of life. The Program of Main Family Building (MKU) initiated by the Indonesian BMT Association (PBMTI) is a new idea as an effort of Baitul Maal wa Tamwil (BMT) to be involved in empowerment programs, especially family. The MKU program launched since 2014 needs to be evaluated to find out how effective the program is. This research focuses on program identification through four indicators of effectiveness, namely the accuracy of targets, socialization, objectives and monitoring program. This study uses a quantitative approach by distributing questionnaires to 32 respondents consisting of all MKU program members. The finding revealed that the MKU program implemented by the KSPPS Tumang BMT showed sufficient effectiveness or $72.7 \%$ effective.

\section{ABSTRAK}

Pengentasan kemiskinan adalah agenda umum pembangunan di seluruh dunia, tidak terkecuali Indonesia. Pembangunan berkualitas dan berkelanjutan adalah yang mampu memberdayakan masyarakat untuk pengentasan kemiskinan dan peningkatan kualitas hidup. Program Membangun Keluarga Utama (MKU) yang diprakarsai oleh Perhimpunan BMT Indonesia (PBMTI) adalah ide baru sebagai upaya Baitul Maal wa Tamwil (BMT) untuk terlibat dalam program pemberdayaan, terutama keluarga. Program MKU yang diluncurkan sejak 2014 perlu dievaluasi untuk mengetahui seberapa efektif program tersebut. Penelitian ini akan fokus pada identifikasi program melalui empat indikator efektivitas, yaitu ketepatan sasaran, sosialisasi, sasaran dan pemantauan program. Penelitian ini menggunakan pendekatan kuantitatif dengan menyebarkan kuesioner kepada 32 responden yang terdiri dari semua anggota program MKU. Hasil penelitian menunjukkan bahwa program MKU yang telah dilaksanakan oleh KSPPS BMT Tumang menunjukkan tingkat efektivitas yang cukup atau 72,7\% efektif. 


\section{Pendahuluan}

Kemiskinan selalu menjadi isu utama dalam pembangunan. Ia diidentikkan dengan penyakit sosial sehingga pemberantasannya menjadi bagian dari agenda Millennium Development Goals (MDG's). Tujuan pemberantasan kemiskinan sejatinya adalah menciptakan kesejahteraan. Dan inilah yang menjadi tugas negara yang ditetapkan oleh pendiri bangsa. Di antara indikator keberhasilan pembangunan suatu negara ialah turunnya tingkat kemiskinan. Jika merujuk pada Badan Pusat Statistik (BPS) tingkat kemiskinan di Indonesia terbagi menjadi dua, masyarakat perkotaan dan pedesaan. Angka kemiskinan di tingkat perkotaan pada Maret 2018 sebesar 7,02 persen sementara di daerah pedesaan sebesar 13,2 persen(1).

Disparitas tingkat kemiskinan di daerah pedesaan jauh lebih besar dari perkotaan. Salah satu penyebab yang disampaikan dalam penelitian Suryawati adalah kebijakan anti kemiskinan yang justru melestarikan kemiskinan atau yang disebut dengan policy induces processes (15). Dari fenomena di atas, tentu berbagai program pembangunan untuk pengentasan kemiskinan dan peningkatan kualitas hidup manusia khususnya di pedesaan menjadi prioritas. Program pembangunan yang berkesinambungan dan berkualitas menjadi kunci kebijakan bersama selanjutnya. Di antara program pembangunan yang mengikutsertakan masyarakat sebagai usaha dalam mengentaskan kemiskinan di desa adalah Membangun Keluarga Utama (MKU). Sejatinya MKU merupakan program yang digagas oleh Perhimpunan BMT se-Indonesia (PBMTI). Program MKU ini bersinergi dengan lembaga keuangan Baitul Maal wa Tamwil (BMT) yang berada di bawah perhimpunan (PBMTI).

BMT sebagai lembaga keuangan memiliki fungsi sebagai intermediary reserve yang menghubungkan pihak kelebihan dan yang membutuhkan dana sehingga ia diharapkan menjadi jembatan. Program MKU yang dikelola oleh BMT merupakan sebuah gerakan "bottom up programme" yang memberdayakan dan memandirikan dengan memanfaatkan potensi setiap anggota keluarga.
Proses pemberdayaan program MKU diprioritaskan pada sisi rohani atau keagamaan peserta dan pengentasan kebodohan melalui peningkatan literasi keuangan yang secara langsung difasilitasi oleh BMT sebagai mediator. Program MKU juga menjadi tempat silaturahim, komunikasi (konsultasi) dan wadah kajian yang menguatkan wawasan keagamaan dan ekonomi keluarga. Dengan adanya program MKU ini diharapkan dapat meningkatkan kualitas hidup masyarakat.

Salah satu program MKU yang secara serius dijalankan oleh PBMTI adalah program MKU yang ada di KSPPS BMT Tumang di Kantor Cabang Suruh yang berada di Kabupaten Semarang, Jawa Tengah. Kegiatan program MKU ini secara rutin diagendakan setiap bulan dan dihadiri oleh ibu - ibu rumah tangga. Mengingat peran keluarga dalam negara sebagai unit terkecil dalam masyarakat yang menentukan kualitas bangsa. Sehingga penelitian ini akan difokuskan pada sejauh mana efektivitas program tersebut untuk mewujudkan masyarakat yang agamis (Islami) dan sejahtera.

\section{Review Kajian Pustaka}

\section{Konsep Efektivitas Program}

Kata efektivitas diserap dari bahasa Inggris yaitu effective. Pertama kali diketahui digunakan di abad ke-14 dengan asli kata effect (16). Effective berarti memproduksi sesuatu (hasil) yang diinginkan. Sedangkan merujuk pada Kamus Besar Bahasa Indonesia (KBBI) efektivitas merupakan kata dasar dari kata efektif yang berarti ada efeknya (akibatnya, pengaruhnya, kesannya (17). Banyak ahli mengungkapkan pengertian dari efektivitas. Subagyo menyebutkan bahwa efektivitas adalah adanya keselarasan antara output dengan maksud (tujuan) yang dikehendaki (13). Efektivitas merupakan suatu kejadian yang dikehendaki atau peristiwa yang ditetapkan, Mahmudi mendefinisikan efektivitas adalah relasi antara output dengan tujuan, semakin besar kontribusi (sumbangan) output terhadap pencapaian tujuan, maka semakin efektif program tersebut (5).

Pengukuran terhadap tingkat kesesuaian program dengan tujuan yang telah ditetapkan 
adalah metode untuk mengetahui efektivitas program. Mengutip pendapat Steers dalam Sutrisno yang mengatakan bahwa hal terbaik untuk mengetahui efektivitas yaitu dengan memperhatikan tiga konsep berkaitan secara bersamaan: 1. Optimalisasi tujuan-tujuan; 2. Perspektif sistem; dan 3. Tekanan pada aspek perilaku manusia dalam organisasi (7).

Menurut teori David Krech, Richard S. Cruthfied dan Egerton L. Ballechey dalam Danim memaparkan ukuran efektivitas dari empat sudut 1. Jumlah hasil yang dikeluarkan; 2. Tingkat kepuasan yang diperoleh; 3. Produk kreatif; 4. Intensitas yang ingin dicapai (3).

Selanjutnya Budiani dalam penelitiannya menyatakan pendapat lain dalam menilai efektivitas suatu program dengan menggunakan variabel - variabel lain sebagai berikut: 1. ketepatan sasaran program, yaitu sejauh mana peserta program sesuai dengan sasaran program yang sudah ditetapkan sebelumnya; 2. sosialisasi program, yaitu kemampuan penyelenggara program dalam melakukan sosialisasi program sehingga informasi mengenai pelaksanaan program dapat tersampaikan kepada masyarakat pada umumnya dan sasaran peserta program pada khususnya; 3. tujuan program yaitu sejauh mana kesesuaian antara hasil pelaksanaan program dengan tujuan program yang telah ditetapkan sebelumnya; 4. pemantauan program yaitu kegiatan yang dilakukan setelah dilaksanakannya program sebagai bentuk monitoring terhadap peserta program (2).

Kemudian Campbell dkk juga meringkas 26 daftar variabel dependen yang diperolehnya dari survei literatur efektivitas organisasi yaitu 1. efektivitas keseluruhan; 2. Produktivitas; 3. efisiensi; 4. profit; 5. Kualitas; 6. kecelakaan (accident); 7. pertumbuhan; 8. absensi; 9. pergantian; 10. kepuasan; 11. motivasi; 12. moral; 13. kontrol; 14 . konflik/kohesi; 15. fleksibilitas/adaptasi; 16 . tujuan yang disepakati; 17. peran dan kesesuaian aturan; 18. kemampuan manajerial dalam memberi tugas; 19. kemampuan interpersonal manajerial; 20. manajemen informasi dan komunikasi; 21. kesiapan; 22. pemanfaatan lingkungan; 23. evaluasi dari pihak luar; 24. stabilitas; 25 . internalisasi tujuan organisasi;
26. nilai (value) dari sumber daya manusia(11).

Dari pengertian efektivitas yang ditulis oleh para ahli maka peneliti memandang bahwa efektivitas program dapat dilihat sebagai alat ukur untuk mengetahui kesesuaian program dengan tujuan yang ditetapkan atau dengan membandingkan antara hasil dan perencanaan yang telah disepakati.

\section{Konsep Pemberdayaan}

Menurut Nasdian upaya pembangunan sejauh ini pada dasarnya berfokus pada pemberdayaan komunitas dengan melakukan pembagian kekuasaan (power sharing) sehingga masyarakat memiliki kemampuan dan kesetaraan dengan pemangku kepentingan lainnya. Oleh sebab itu, semua pemangku kepentingan berperan sebagai pelaku perubahan dalam proses pembangunan yang berusaha untuk memberdayakan anggota masyarakat dari yang kurang mampu menjadi lebih diberdayakan di tingkat individu hingga kelompok sosial untuk menuju kehidupan yang lebih baik (9).

Menurut Suharto dalam Muljono pemberdayaan mengacu pada kemampuan orang atau masyarakat yang rentan dan lemah, sehingga mereka memiliki kekuatan dan kemampuan dalam: 1. Memenuhi kebutuhan dasar sehingga mereka mendapatkan kebebasan (freedom); 2. Mencapai sumber daya produktif yang memungkinkan mereka untuk meningkatkan pendapatan dan mendapatkan barang dan jasa yang mereka butuhkan 3. Berpartisipasi dalam proses pembangunan dan keputusankeputusan yang dapat mempengaruhi kehidupan mereka (8).

Pemberdayaan menurut Nawawi diidentifikasi sebagai sebuah proses dan tujuan. Sebagai suatu proses, pemberdayaan merupakan rentetan dari upaya yang bertujuan memperkuat keberdayaan bagi kelompok lemah yang ada di masyarakat. Sedangkan sebagai tujuan, pemberdayaan mengarah pada hasil yang ingin dituju yaitu sebuah komunitas yang berdaya, memiliki kemampuan untuk memenuhi kebutuhan hidupnya yang bersifat fisik, ekonomi, maupun sosial. Selain itu memiliki kekuasaan 
atau pengetahuan sehingga tumbuh kepercayaan diri, hingga mampu menyampaikan harapan-harapannya, memiliki penghasilan sendiri, berperan dalam aksi sosial, dan mandiri dalam melakukan kewajiban hidupnya. Pengertian pemberdayaan sebagai tujuan umumnya dijadikan sebagai indikator kesuksesan pemberdayaan (10).

Pemberdayaan adalah usaha untuk membangun kekuatan atau daya itu sendiri, dengan cara mendorong, memotivasi dan meningkatkan kesadaran atas kemampuan dan berusaha untuk mengembangkannya. Selebihnya, usaha ini diikuti dengan mengokohkan kemampuan yang dimiliki oleh komunitas itu sendiri. Dalam situasi ini diperlukan tahapan-tahapan yang lebih positif, tidak cukup dengan hanya menjadikan lingkungan dan suasana yang kondusif. Seperti hal - hal yang menyangkut penyediaan berbagai masukan (input), diikuti penyaluran ke berbagai peluang (opportunities) yang membuat masyarakat menjadi semakin berdaya (4).

Dengan demikian, dapat disimpulkan bahwa pemberdayaan merupakan upaya untuk menguatkan masyarakat yang lemah dengan menjadikan mereka sebagai subjek untuk mendorong hidup yang produktif dan lebih baik.

\section{Pemberdayaan Masyarakat Islami}

Pemberdayaan (konteks terapan) adalah suatu pembangunan yang masih relevan bagi perkembangan masyarakat menuju the real civil society atau lebih tepat masyarakat yang madani yaitu masyarakat yang didasarkan pada aspek Theisme yang benar. Aspek Theisme bersifat mendesak untuk menghindari sifat materialistik dan empirik tanpa ikatan antara intelektualitas dan spiritualitas (14).

Meskipun diakui hal ini tidak mudah untuk mendapatkan tujuan yang maksimal namun menurut Matthoriq dkk dengan adanya kemudahan teknologi dan informasi serta keterbukaan politik diharapkan dapat memberi peningkatkan pada kapasitas keberdayaan masyarakat (6). Khususnya masyarakat yang tinggal di pedesaan.

Selanjutnya Mathoriq dkk menilai bahwa Islam memandang suatu keberdayaan masyarakat yang madani sebagai suatu hal yang urgen. Pemberdayaan dalam perspektif Islam memiliki pendekatan-pendekatan yang strategis dan holistik. Terkait hal itu, Islam mempunyai paradigmanya sendiri dalam memandang suatu pemberdayaan (6).

Menurut Istiqomah dalam Jurnal Administrasi Publik yang ditulis oleh Matthoriq dkk bahwa pemberdayaan dalam konteks pengembangan masyarakat Islam adalah sebuah telaah kepada masyarakat untuk menjadikan mereka mandiri mengerjakan kewajiban - kewajiban dalam memperbaiki kualitas hidupnya yang menyangkut kesejahteraan dan keselamatannya, baik di dunia maupun di akhirat (6).

Sehingga tulisan ini melihat bahwa pemberdayaan masyarakat Islami merupakan alternatif pendekatan kepada masyarakat yang dilakukan dengan memanfaatkan kesamaan kepercayaan atau teisme. Pemberdayaan masyarakat Islami berusaha menggunakan kedekatan faktor emosi dengan harapan, tujuan dari pemberdayaan mudah untuk dicapai.

\section{Program Membangun Keluarga} Utama

Program Membangun Keluarga Utama (MKU) adalah upaya yang diprakarsai oleh gerakan BMT untuk membangun keluarga Indonesia yang bahagia melalui serangkaian kegiatan serta pembiasaan aktivitas hidup yang baik dan mulia sesuai dengan tuntunan Islam. Aktivitas hidup tersebut antara lain majelis ta'lim, qiyamul lail, sholat berjamaah di masjid, bersedekah, membaca al Qur'an, dan berta'awun.

Keluarga merupakan bagian terkecil dari komunitas masyarakat. Setiap anggota keluarga mempunyai tanggung jawab masing-masing, selain bertindak untuk dirinya sebagai individu juga bertindak secara sosial, peduli lingkungan, saling menghormati dan bertoleransi.

Allah SWT telah berfirman dalam Q.S At Tahrim [66] : 6 mengenai pentingnya peran dan fungsi sebuah keluarga dalam suatu masyarakat sehingga setiap pribadi orang beriman dituntut untuk menjaga dirinya dan keluarganya. 
MKU sebagai program pada dasarnya memiliki aspek layanan kepada para pesertanya. Layanan itu antara lain: 1. Pembinaan ruhiyah setiap pekanan atau bulanan; 2. Bagi peserta yang sakit akan dibesuk dan didoakan; 3. Mendapatkan fasilitas pemeriksaan kesehatan, sosialisasi gaya hidup dan lain-lain; 4. Mendapatkan majelis taklim setiap bulan dengan materi keluarga yang menarik, fiqih dan lain-lain

Program MKU dapat dilihat dalam beberapa sisi utama. Dari sisi keluarga peserta, MKU merupakan sarana pembinaan, pendidikan dan pembiasaan melakukan amal sholeh, sehingga menjadi keluarga utama. Sedangkan dari sisi BMT, MKU bertujuan membentuk jamaah yang solid sebagai basis komunitas BMT. Komunitas BMT memiliki peran penting secara manajemen yaitu: 1 . Sebagai pelanggan yang dilayani, baik dalam aspek tamwil maupun mal. Layanan yang mencakup masalah keuangan dan sebagian besar bidang kehidupan karena merupakan sasaran dakwah aktivitas BMT; 2. Komunitas BMT berperan sangat penting dalam mendorong perkembangan BMT. Komunitas yang solid akan menjamin keberlangsungan aspek keuangan BMT, yang pada gilirannya memberi manfaat bagi semua. Peningkatan kepatuhan kepada aspek syariah pun tak sekedar pada akad atau prosedur aktivitas, melainkan pada spirit dan mengarah pada tujuan syariah itu sendiri. 3. Komunitas BMT menjadi sumber dari rekrutmen insan/pengelola BMT. Secara tidak langsung mereka akan menjadi humas bagi anggota masyarakat lainnya tentang kebaikan dan prospek bekerja di BMT bagi para generasi muda Muslim.

Dari sisi kepentingan negeri, MKU bertujuan membangun Indonesia menjadi baldatun thoyibatun wa robbun ghofur. Sebuah negeri yang demikian mensyaratkan keberadaan keluarga - keluarga yang baik, sehat, sejahtera, terdidik dan religius. Keluarga yang seperti ini disebut keluarga utama .

Hingga saat ini, belum ada penelitian tentang seberapa besar efektivitas dari program MKU karena belum banyak BMT yang menjalankan program ini. Ada beberapa sebab yaitu, program ini merupakan program yang baru dirilis oleh PBMTI pada tahun
2014. Sehingga BMT yang memprogramkannya memerlukan sumber daya khusus yang fokus mengoperasikan program ini. Dari sekian BMT yang bergabung dengan PBMTI, hanya KSPPS BMT Tumang yang mempunyai divisi khusus yang mengelola program MKU secara serius.

\section{Metodologi Penelitian}

Penelitian ini dilaksanakan selama Maret 2017 hingga Juni 2018 pada program membangun keluarga utama (MKU) di KSPPS BMT Tumang, Jawa Tengah. Dalam penelitian ini metode yang digunakan adalah metode kuantitatif.

Data dalam penelitian ini diambil dari dua sumber, pertama dari peserta program MKU yang selanjutnya disebut sebagai sumber primer. Adapun data primer yang digunakan adalah identitas responden yang menjadi anggota program MKU seperti jenis kelamin, usia, jarak rumah menuju lembaga keuangan/kota serta pernyataan responden terhadap efektivitas program MKU. Sedangkan jumlah sampel yang digunakan berjumlah 32 orang. Jenis sampel ini disebut sampel jenuh karena semua anggota populasi digunakan sebagai sampel. Sumber kedua berasal dari buku-buku, jurnal - jurnal ilmiah serta dokumentasi dari kegiatan program KSPPS BMT Tumang.

Data primer dalam penelitian ini diambil langsung dari lapangan dengan cara membagikan kuesioner kepada peserta program. Peserta program diberikan waktu untuk mengisi seluruh pertanyaan di tempat program MKU dilaksanakan. Sedangkan data sekunder diperoleh dari data laporan dan dokumen tentang program MKU yang didapat dari KSPPS BMT Tumang.

Data diolah menggunakan aplikasi microsoft excell 2007, data dianalisis menggunakan tabel frekuensi untuk melihat data awal responden untuk masing-masing variabel secara tunggal dengan menggunakan aplikasi Microsoft Excel 2007.

Dalam penelitian ini untuk mengukur efetivitas program MKU, peneliti menggunakan teknik persentase oleh Sugiyono dan diperkuat oleh penelitian sebelumnya tentang efektivitas program 
pemberdayaan oleh Budiani dan Satries dengan rumus:

$$
\text { Efektivitas }=\frac{\text { Nilai kelompok }}{\text { Nilai ideal }} \times 100 \%
$$

Semakin besar persentase target yang dicapai maka semakin tinggi pula nilai efektivitas. Adapun nilai ideal untuk mencapai efektivitas yang sempurna dalam penelitian ini adalah 1920. Interpretasi hasil persentase mengacu kepada tabel yang dikembangkan oleh Arikunto (1998) seperti terlihat tabel 1 berikut ini:

Tabel 1 Interpretasi Hasil Persentase

\begin{tabular}{cc}
\hline $\begin{array}{c}\text { Besar Nilai } \\
\text { Efektivitas }\end{array}$ & $\begin{array}{c}\text { Nilai Interpretasi } \\
\text { Efektivitas }\end{array}$ \\
\hline $80 \%-100 \%$ & Tinggi \\
$60 \%-79 \%$ & Cukup \\
$40 \%-59 \%$ & Agak Rendah \\
$20 \%-39 \%$ & Rendah \\
$0 \%-19 \%$ & Sangat Rendah \\
\hline
\end{tabular}

Sedangkan indikator yang digunakan dalam penelitian ini merujuk pada teori efektivitas program oleh Budiani (2) dan Satries (12) yaitu; 1. Ketepatan Sasaran program yaitu peserta merupakan anggota dari KSPPS BMT Tumang yang telah memiliki usaha pribadi/kelompok dan waktu dan tempat dijalankannya sesuai dan memadai. 2. Sosialisasi program yaitu meliputi frekuensi, media dan metode sosialisasi yang dapat diketahui oleh anggota MKU; 3. Tujuan program yaitu membangun jiwa kemandirian, kewirausahawanan dan membentuk komunitas yang solid di diri anggota MKU; 4. Pemantauan program yaitu anggota MKU merasa atau mengakui adanya proses pemantauan dari pihak KSPPS BMT Tumang.

\section{Hasil dan Diskusi}

\section{Aspek Ketepatan Sasaran Program}

Ketepatan sasaran merupakan sejauh mana peserta program tepat dengan sasaran yang dibutuhkan program tersebut. Kegiatan MKU dianggap tepat sasaran apabila sasaran merupakan anggota yang telah berkeluarga, anggota KSPPS BMT Tumang, mengetahui waktu dan tempat pelaksanaan program.
Sasaran utama program MKU dijalankan adalah peserta yang telah berkeluarga yaitu yang memiliki pasangan sah. Mengingat keluarga memegang peran penting terhadap pembentukan lingkungan sosial secara tidak langsung. Selanjutnya peserta merupakan anggota dari KSPPS BMT Tumang, dengan pertimbangan, MKU merupakan kegiatan yang diinisiasi oleh Perhimpunan BMT seIndonesia (PBMTI). Hadirnya program MKU, merupakan upaya dari PBMTI untuk memberikan kontribusi langsung terhadap pemberdayaan masyarakat di bidang ekonomi dan agama.

Nilai kelompok untuk indikator program MKU dari aspek sasaran program mendapatkan nilai sebesar 375 dengan nilai ideal 512. Dengan demikian didapat nilai efektivitas:

$$
\begin{aligned}
& =\frac{\text { Nilai kelompok }}{\text { Nilai ideal }} \times 100 \% \\
& =\frac{375}{512} \times 100 \% \\
& =73 \%
\end{aligned}
$$

Berdasarkan tabel 1 tentang interpretasi dari Arikunto, maka efektivitas program dari aspek ketepatan sasaran program memiliki efektivitas cukup. Artinya dalam pelaksanaan program MKU tidak semua peserta mengerti sasaran yang diinginkan oleh program MKU. Hal ini, dapat diurai dari jawaban peserta tentang persepsi mereka mengenai program ini ditujukan pada tabel 2 berikut ini.

Tabel 2

Persepsi Program MKU Efektivitas Program MKU Aspek Ketepatan Sasaran Kategori Program

\begin{tabular}{lcc}
\cline { 2 - 3 } & $\mathrm{n}$ & $\%$ \\
\hline Tinggi & 8 & 25,0 \\
\hline Cukup & 21 & 65,6 \\
\hline $\begin{array}{l}\text { Agak } \\
\text { Rendah }\end{array}$ & 3 & 9,4 \\
\hline Rendah & 0 & 0 \\
\hline $\begin{array}{l}\text { Sangat } \\
\text { Rendah }\end{array}$ & 0 & 0 \\
\hline Total & 32 & 100,00 \\
\hline
\end{tabular}


Dari tabel di atas dapat dilihat bahwa sebagian responden menyatakan bahwa ketepatan sasaran prada program MKU termasuk dalam kategori cukup yaitu sebesar 65,6 persen. Selanjutnya diikuti dengan kategori ketepatan sasaran program yang tinggi sebesar 25 persen. Kemudian dilanjutkan dengan kategori ketepatan sasaran program agak rendah sebesar 9,4 persen.

Mencermati hasil di atas, maka dapat dikatakan bahwa sasaran program sudah berjalan cukup efektif terbukti dari jawaban mayoritas peserta program MKU. Dari jawaban responden masih ada beberapa yang mengisyaratkan jika mereka bukan dari anggota KSPPS BMT Tumang dan belum berkeluarga, ini merupakan isyarat agar sebaiknya program MKU tidak hanya bagi yang sudah berkeluarga dan anggota dari KSPPS BMT Tumang namun juga dibuka untuk umum. Walaupun isyarat ini masih relatif kecil yaitu dibawah 10 persen.

Melihat hasil di atas, pihak penyelenggara program MKU tidak menampik adanya peserta di luar dari sasaran target. Hal ini dinilai positif bagi penyelenggara MKU yaitu KSPPS BMT Tumang disebabkan program MKU memiliki muatan iklan atau promosi bagi masyarakat umum untuk mengenal BMT Tumang tidak hanya sebagai lembaga keuangan namun juga lembaga sosial yang berorientasi kepada kerukunan masyarakat .

\section{Aspek Sosialisasi Program}

Sosialisasi program merupakan kemampuan penyelenggara program dalam melakukan sosialisasi program sehingga informasi mengenai pelaksanaan dapat tersampaikan kepada peserta program.

Adapun sosialisasi yang telah dilakukan oleh penyelenggara program MKU di antaranya melalui musyawarah atau rembuk bersama tokoh desa, warga masyarakat yang ditemui secara langsung. Selain itu ada juga melalui media lain seperti majalah, radio dan banner. Berdasarkan jawaban responden didapat nilai efektivitas sosialisasi program MKU sebesar 628 dari nilai ideal sebesar 896.

$$
\begin{aligned}
\text { Efektivitas } & =\frac{\text { Nilai kelompok }}{\text { Nilai ideal }} \times 100 \% \\
& =\frac{528}{896} \times 100 \% \\
& =70 \%
\end{aligned}
$$

Berdasarkan tabel interpretasi dari Arikunto, maka efektivitas program dari aspek sosialisasi program MKU memiliki efektivitas cukup. Artinya dalam pelaksanaan program MKU tidak semua peserta mengetahui sosialisasi yang telah dilakukan oleh penyelenggara program MKU. Hal ini, dapat diuraikan dari jawaban para peserta tentang persepsi mereka mengenai program ini ditujukan pada tabel 3 berikut ini.

Tabel 3

Program Yang Ditawarkan

Efektivitas Program MKU

Kategori Aspek Ketepatan Sasaran Program

\begin{tabular}{lcc} 
& $\mathrm{n}$ & $\%$ \\
\hline Tinggi & 5 & 15,0 \\
\hline Cukup & 21 & 65,6 \\
\hline $\begin{array}{l}\text { Agak } \\
\text { Rendah }\end{array}$ & 5 & 15,6 \\
\hline Rendah & 1 & 3,1 \\
\hline $\begin{array}{l}\text { Sangat } \\
\text { Rendah }\end{array}$ & 0 & 0 \\
\hline Total & 32 & 100,00 \\
\hline
\end{tabular}

Berdasarkan tabel 3 terlihat bahwa responden menyatakan bahwa sosialisasi tentang program MKU termasuk dalam kategori cukup sebesar 65,6 persen. Disusul oleh kategori tinggi dan agak rendah, masing-masing sebesar 15,6 persen. Dan kategori rendah sebesar 3,1 persen.

Menurut pihak penyelenggara sosialisasi dinilai paling efektif melalui tokoh masyarakat, disebabkan faktor sosiologi dari masyarakat desa yang masih kental dengan semangat gotong royong. Semangat kebersamaan yang dibangun antar warga membuat program sosialisasi cukup efektif berjalan. Namun masih ada yang menilai bahwa aspek sosialisasi masih rendah, hal ini memberikan kesempatan kepada penyelenggara untuk memanfaatkan media dan metode lain dalam sosialisasi seperti 
memaksimalkan peran teknologi informasi melalui media internet dan lain sebagainya .

\section{Aspek Tujuan Program}

Tujuan program merupakan kesesuaian antara tujuan awal dengan hasil yang dicapai. Tujuan yang dimaksud juga mencakup kesesuaian program terhadap pemenuhan kebutuhan masyarakat. Ketetapan suatu program dalam mengatasi masalah tertentu merupakan suatu bentuk kesesuaian yang tinggi dalam program.

Pada penelitian ini diukur bagaimana program MKU dapat mengatasi masalah dalam keharmonisan berkeluarga, kerukunan antar masyarakat hingga wawasan keagamaan yang disampaikan oleh pemateri dalam program MKU. Dalam aspek tujuan program MKU didapat nilai keseluruhan jawaban responden sebesar 289 dari nilai ideal efektivitas sebesar 384 .

$$
\begin{aligned}
\text { Efektivitas } & =\frac{\text { Nilai kelompok }}{\text { Nilai ideal }} \times 100 \% \\
& =\frac{289}{384} \times 100 \% \\
& =75 \%
\end{aligned}
$$

Berdasarkan tabel interpretasi dari Arikunto maka angka 75\% menghasilkan nilai cukup bagi efektivitas dari aspek tujuan program MKU. Angka ini dinilai cukup baik dan menandakan program yang selama ini dikerjakan oleh KSPPS BMT Tumang cukup membantu peserta dalam membangun keharmonisan keluarga, kerukunan masyarakat melalui nilai-nilai agama yang menjadi materi pertemuan MKU. Sedangkan untuk sebaran kategori dari jawaban responden mengenai efektivitas tujuan program MKU dapat dilihat dari tabel 4 berikut.
Tabel 4

\begin{tabular}{|c|c|c|}
\hline \multirow[t]{2}{*}{ Kategori } & \multicolumn{2}{|c|}{$\begin{array}{c}\text { Efektivitas Program MKU } \\
\text { Aspek Ketepatan Sasaran } \\
\text { Program }\end{array}$} \\
\hline & $\mathrm{n}$ & $\%$ \\
\hline Tinggi & 10 & 31,3 \\
\hline Cukup & 17 & 53,1 \\
\hline $\begin{array}{l}\text { Agak } \\
\text { Rendah }\end{array}$ & 4 & 12,5 \\
\hline Rendah & 1 & 3,1 \\
\hline $\begin{array}{l}\text { Sangat } \\
\text { Rendah }\end{array}$ & 0 & 0 \\
\hline Total & 32 & 100,00 \\
\hline
\end{tabular}

Kategori Jawaban Terhadap Program MKU

Berdasarkan tabel 4, terlihat bahwa tujuan program masuk dalam kategori cukup yaitu sebesar 53,3 persen. Selanjutnya, kategori tinggi dipilih oleh responden sebesar 31,3 persen. Kemudian dilanjutkan oleh kategori tujuan program agak rendah sebesar 12,5 persen dan diakhiri oleh tujuan program dengan kategori rendah sebesar 3,1 persen.

Mencermati tabel 4 tentang kategori jawaban responden terhadap program MKU, terlihat bahwa mayoritas jawaban dari peserta adalah cukup efektif. Hal ini menunjukkan bahwasanya peserta program MKU merasa keluarga mereka kian harmonis dan rukun. Dengan demikian dapat dikatakan tujuan program MKU dapat dikatakan cukup berhasil dan diakui oleh peserta program MKU.

\section{Pemantauan Program}

Pemantauan program adalah kegiatan yang dilakukan setelah dilaksanakannya program sebagai bentuk perhatian kepada peserta program baik secara substansial maupun secara manajemen. Pada penelitian ini kegiatan program MKU mencakup kegiatan jamaah dalam upaya mendorong kerukunan dalam masyarakat. Berdasarkan jawaban responden didapat nilai keseluruhan dari aspek pemantauan program sebesar 95 dari nilai ideal sebesar 128 .

$$
\begin{aligned}
\text { Efektivitas } & =\frac{\text { Nilai kelompok }}{\text { Nilai ideal }} \times 100 \% \\
& =\frac{95}{128} \times 100 \% \\
& =74 \%
\end{aligned}
$$


Nilai yang telah didapat, selanjutnya dibandingkan dengan tabel interpretasi dari Arikunto maka menghasilkan nilai cukup untuk indikator pemantauan setelah program MKU yaitu sebesar 74 persen. Nilai tersebut dinilai cukup baik, mengingat jarak dan intensitas pertemuan setiap program jauh dan jarang. Kesulitan ini dapat diatasi dengan loyalitas dan penambahan jumlah pengelola program MKU agar pemantauan program dapat menjadi bahan evaluasi yang baik bagi keberlanjutan program MKU di masa yang akan datang.

Tabel 5

Efektivitas Program MKU

\begin{tabular}{lcc}
\hline \multirow{2}{*}{ Kategori } & \multicolumn{2}{c}{$\begin{array}{c}\text { Efektivitas Program MKU } \\
\text { Aspek Ketepatan Sasaran } \\
\text { Program }\end{array}$} \\
\cline { 2 - 3 } & $\mathrm{n}$ & $\%$ \\
\hline Tinggi & 9 & 28,1 \\
\hline Cukup & 15 & 46,9 \\
\hline $\begin{array}{l}\text { Agak } \\
\text { Rendah }\end{array}$ & 6 & 18,8 \\
\hline Rendah & 2 & 6,3 \\
\hline $\begin{array}{l}\text { Sangat } \\
\text { Rendah }\end{array}$ & 0 & 0 \\
\hline Total & 32 & 100,00 \\
\hline
\end{tabular}

Berdasarkan tabel 5 berikut, dapat dilihat bahwa sebagian besar responden menyatakan bahwa pemantauan program termasuk dalam kategori cukup dengan nilai sebesar 46,9 persen. Selanjutnya diikuti dengan aspek pemantauan program tinggi sebesar 28,1 persen. Kemudian dilanjutkan dengan aspek pemantauan program agak rendah sebesar 18,3 persen dan diakhiri dengan aspek pemantauan program rendah sebesar 6,3 persen.

Setelah dilakukan analisis mengenai data sebaran efektivitas dari aspek pemantauan program MKU maka masih ada dari peserta yang menilai bahwa efektivitas pemantauan masih rendah sebanyak dua orang. Ini tentu membuka kesempatan bagi penyelenggara program MKU agar metode pemantauan berjalan dengan baik sehingga semua peserta merasa dimonitor terkait program MKU yang telah berjalan.

\section{Efektivitas Program Membangun Keluarga Utama}

Analisis terhadap efektivitas program Membangun Keluarga Utama yang diselenggarakan oleh KSPPS BMT Tumang dilakukan dengan cara mengumpulkan data tentang persepsi peserta terhadap indikator efektivitas program yang meliputi ketepatan sasaran program, sosialisasi program, tujuan program, dan pemantauan program. Analisis ini dilakukan setelah dilakukan survei kepada peserta program yang berjumlah 32 responden. Nilai efektivitas program Membangun Keluarga Utama berdasarkan hasil persepsi anggota yaitu jumlah nilai efektivitas program keseluruhan yaitu 1.387 poin dan nilai ideal yaitu 1.920 poin, dengan demikian didapat nilai efektivitas sebesar $72.2 \%$.

$$
\begin{aligned}
\text { Efektivitas } & =\frac{\text { Nilai kelompok }}{\text { Nilai ideal }} \times 100 \% \\
& =\frac{1387}{1920} \times 100 \% \\
& =72,7 \%
\end{aligned}
$$

Berdasarkan tabel interpretasi dari Arikunto, maka efektivitas program Membangun Keluarga Utama (MKU) KSPPS BMT Tumang memiliki efektivitas cukup. Artinya, dalam pelaksanaan program MKU ini, masih ada sasaran, sosialisasi program, tujuan, dan pemantauan program yang dapat dimaksimalkan sehingga bisa mencapai efektivitas yang tinggi.

Adapun rekapitulasi dari nilai efektivitas program MKU dapat dilihat dari tabel 6 berikut ini: 
Tabel 6

Rekapitulasi Nilai Efektivitas Program MKU

\begin{tabular}{cccc}
\hline No & Indikator & Persentase & $\begin{array}{l}\text { Interpretasi } \\
\text { Nilai } \\
\text { Efektivitas }\end{array}$ \\
\hline 1 & $\begin{array}{l}\text { Ketepatan } \\
\text { sasaran } \\
\text { program }\end{array}$ & $73 \%$ & $\begin{array}{l}\text { Cukup } \\
\text { efektif }\end{array}$ \\
\hline 2 & $\begin{array}{l}\text { Sosialisasi } \\
\text { program }\end{array}$ & $70 \%$ & $\begin{array}{l}\text { Cukup } \\
\text { efektif }\end{array}$ \\
\hline 3 & $\begin{array}{l}\text { Tujuan } \\
\text { program }\end{array}$ & $74 \%$ & $\begin{array}{l}\text { Cukup } \\
\text { efektif }\end{array}$ \\
\hline 4 & $\begin{array}{l}\text { Pemantauan } \\
\text { program }\end{array}$ & $74 \%$ & $\begin{array}{l}\text { Cukup } \\
\text { efektif }\end{array}$ \\
\hline
\end{tabular}

Berdasarkan tabel di atas, maka dapat dilihat bahwa dari keempat indikator efektivitas program, semuanya menunjukkan nilai interpretasi yang sama yaitu cukup efektif. Namun persentase masing-masing indikator tidak sama. Dari keempat indikator yang ada, nilai terendah didapat oleh indikator sosialisasi sebesar 70 persen dan yang tertinggi didapat oleh indikator tujuan program yaitu sebesar 75 persen.

Rendahnya nilai sosialisasi program memang disebabkan oleh faktor sosiologis masyarakat desa yang merasa sudah cukup dengan informasi yang didapat dari tokoh desa sedangkan tujuan program mendapatkan nilai persentase yang besar dikarenakan sebagian besar peserta yang telah dibentuk oleh program ini adalah berasal dari keluarga yang cukup harmonis dan rukun. Sehingga kehadiran program MKU dinilai cukup efektif khususnya menjaga keharmonisan keluarga dan kerukunan warga.

\section{Kesimpulan}

Berdasarkan hasil penelitian yang dilakukan terhadap 32 peserta program MKU yang diselenggarakan oleh KSPPS BMT Tumang terhadap empat indikator efektivitas program maka didapat hasil sebagai berikut: pertama, untuk efektivitas dari aspek ketepatan sasaran program yang ditunjukkan untuk peserta yang telah berkeluarga dan anggota dari KSPPS BMT Tumang berjalan dengan cukup efektif. Hal ini terlihat dari nilai indikator ketepatan sasaran program sebesar 73\%. Dengan skor sebesar 375 dari 512 skor ideal. Artinya sebagian besar peserta menunjukkan pengetahuan mereka terkait kesesuaian diri mereka untuk program MKU namun masih membuka sedikit ruang untuk dibukanya kesempatan bagi yang belum berkeluarga dan bukan anggota KSPPS BMT Tumang untuk ikut dalam program tersebut. Hal ini diyakini akan berdampak positif bagi perkembangan KSPPS BMT Tumang sendiri. Kedua, untuk efektivitas dari aspek sosialisasi program, dinilai cukup efektif dengan skor 628 dari 896 skor ideal atau $70 \%$. Di sini terdapat fenomena bahwa indikator ini merupakan indikator dengan nilai terendah dibandingkan tiga indikator lainnya. Namun nilai dari efektivitas masih cukup baik, hanya saja efektivitas dari sosialisasi yang telah dilakukan perlu ditingkatkan dengan memanfaatkan semangat gotong royong yang dimiliki peserta program MKU. Ketiga, untuk efektivitas dari aspek tujuan program yang terdiri dari keharmonisan keluarga yang tercipta dan kerukunan warga melalui materi agama yang disajikan dalam program MKU dinilai cukup efektif. Besaran efektivitas yaitu $75 \%$ dengan rincian skor 289 dari skor ideal yaitu 384. Hal ini dikarenakan dalam program MKU selain materi agama terselip informasi atau pengetahuan tentang keuangan yang disampaikan kepada peserta program. Sehingga terjadi dialog yang baik antara penyelenggara MKU yaitu KSPPS BMT Tumang selaku lembaga keuangan terhadap anggota dari kalangan masyarakat. Dialog ini yang membangun nilai kekeluargaan antara penyelenggara dan peserta sehingga ada jalinan keakraban antara peserta dan KSPPS BMT Tumang. Keempat, untuk efektivitas dari aspek pemantauan program, hasil yang didapat cukup efektif. Dimana skor yang didapat sebesar 95 dari skor ideal sebesar 128 atau $74 \%$. Adapun kendala yang sulit dihadapi oleh peserta dalam pemantauan adalah jumlah personel penyelenggara MKU yang sedikit dan jarak tempuh menuju tempat yang cukup jauh. Sehingga proses pemantauan dilakukan cukup menyulitkan. Kelima, dari hasil pengukuran efektivitas maka program MKU yang diselenggarakan oleh KSPPS BMT Tumang dapat dikatakan cukup efektif dengan skor $72,7 \%$. Hal ini didasarkan pada jawaban responden atas empat indikator efektivitas program pemberdayaan. 


\section{References}

1. Badan Pusat Statistik. Profil

Kemiskinan di Indonesia Maret 2018.

2. Budiani NW. Efektivitas Program Penanggulangan Pengangguran Karang Taruna "Eka Taruna Bhakti" Desa Sumerta Kelod Kecamatan Denpasar Timur Kota Denpasar . INPUT Jurnal Ekonomi dan Sosial; Vol. 1, No. 2 Februari 2009.

3. Danim S. Motivasi, Kepemimpinan \& Efektivitas Kelompok . Jakarta. Rineka cipta. 2004.

4. Kartasasmita G, Studies (Indonesia) C for I and D. Pembangunan Untuk Rakyat: Memadukan Pertumbuhan Dan Pemerataan. CIDES, 1996.

5. Mahmudi. Manajemen Kinerja Sektor Publik. Yogyakarta: UPP AMP YKPN, 2005.

6. Matthoriq M. Aktualisasi Nilai Islam dalam Pemberdayaan Masyarakat Pesisir (Studi pada Masyarakat Bajulmati, Gajahrejo, Kecamatan Gedangan Kabupaten Malang). Jurnal Administrasi Publik 2: 426-432-432, 2014.

7. M.Si PDHES. Budaya Organisasi. Prenada Media, 2019.

8. Muljono P, Burhanuddin, Bakhtiar Y. Upaya Pemberdayaan Masyarakat Dan Pengentasan Kemiskinan Melalui Model Posdaya (Pos Pemberdayaan Keluarga) [Online]. Prosiding Seminar Hasil-Hasil Penelitian IPB 2009.

9. Nasdian FT. Pengembangan Masyarakat. Yayasan Pustaka Obor Indonesia, 2014.
10. Nawawi I. Pembangunan Dan Problema Masyarakat. Surabaya: Putra Media Nusantara, 2009.

11. P. Campbell J, A. Bownas D, G. Peterson N, D. Dunnette M. The Measurement of Organizational Effectiveness: A Review of Relevant Research and Opinion. .

12. Satries WI. Efektivitas Program Pemberdayaan Pemuda Pada Organisasi Kepemudaan Al Fatih Ibadurrohman Kota Bekasi. Tesis. Universitas Indonesia. 2011.

13. Subagyo AW. Efektivitas program penanggulangan kemiskinan dalam pemberdayaan masyarakat perdesaan :: Studi kasus di Kabupaten Kediri Jawa Timur . Universitas Gadjah Mada: 2000.

14. Suryadi S. Dekontruksi Epistimologi Ilmu-Ilmu Sosial: Sebuah Keniscayaan . Interaktif: Jurnal Ilmu-Ilmu Sosial 1, 2012.

15. Suryawati C. Memahami Kemiskinan Secara Multidimensional. Jurnal Manajemen Pelayanan Kesehatan 8, 2005.

16. Effective | Definition of Effective by Merriam-Webster [Online]. https://www.merriamwebster.com/dictionary/effective [28 Nov. 2018].

17. Arti kata efektif - Kamus Besar Bahasa Indonesia (KBBI) Online [Online]. https://kbbi.web.id/efektif [28 Nov. 2018]. 